\title{
Size distribution of particulate mercury in marine and coastal atmospheres
}

\author{
D. M. Feddersen ${ }^{1,2}$, R. Talbot ${ }^{3}$, H. Mao ${ }^{4}$, and B. C. Sive ${ }^{5}$ \\ ${ }^{1}$ Earth Systems Research Center, Institute for the Study of Earth, Oceans, and Space, University of New Hampshire, Durham, \\ New Hampshire, USA \\ ${ }^{2}$ Department of Chemistry, University of New Hampshire, Durham, New Hampshire, USA \\ ${ }^{3}$ Department of Earth and Atmospheric Sciences, University of Houston, Houston, Texas, USA \\ ${ }^{4}$ Department of Chemistry, SUNY College of Environmental Science and Forestry, Syracuse, New York, USA \\ ${ }^{5}$ Department of Chemistry, Appalachian State University, Boone, North Carolina, USA
}

Correspondence to: D. M. Feddersen (dara.feddersen@ comcast.net)

Received: 2 May 2012 - Published in Atmos. Chem. Phys. Discuss.: 8 June 2012

Revised: 20 October 2012 - Accepted: 25 October 2012 - Published: 20 November 2012

\begin{abstract}
A study was conducted to determine the size distribution of particulate mercury $\left(\mathrm{Hg}^{\mathrm{P}}\right)$ at a marine and coastal site, and to compare the seasonal variability at both sites. Data was collected during summer 2009 and 2010, winter 2010, and spring 2010. Two cascade impactors were used to collect $\mathrm{Hg}^{\mathrm{P}}$ in ten size fractions ranging from $>10 \mu \mathrm{m}$ to $<0.4 \mu \mathrm{m}$. During summer $2009, \mathrm{Hg}^{\mathrm{P}}$ was found mainly (50-60\%) in coarse fractions, 1.1 to $5.8 \mu \mathrm{m}$, composed of sea salt particles at both our coastal site (Thompson Farm) and marine site (Appledore Island). In winter, $\mathrm{Hg}^{\mathrm{P}}$ at Thompson Farm was dominated (65\%) by fine particles, while in spring and summer 2010 , at both sites, $\mathrm{Hg}^{\mathrm{P}}$ was distributed across the coarse and fine fractions (40\% each). Using bulk filters to collect total $\mathrm{Hg}^{\mathrm{P}}$, we show a diurnal cycle that matches that of gaseous elemental mercury. Finally, dry deposition rates of $\mathrm{Hg}^{\mathrm{P}}$ were calculated to be $1.7-2.8 \mathrm{ng} \mathrm{m}^{-2}$ day $^{-1}$ in the summer, $4.6 \mathrm{ng} \mathrm{m}^{-2}$ day $^{-1}$ in the winter, and $2.5 \mathrm{ng} \mathrm{m}^{-2}$ day $^{-1}$ in the spring.
\end{abstract}

\section{Introduction}

Understanding mercury transport and chemical transformations in the atmosphere is a key component to establishing its global cycle. Schroeder and Munthe (1998) summarized the physical, chemical and toxicological properties of atmospheric mercury, as well as various atmospheric pathways including anthropogenic and natural sources, aerial transport and distribution, chemical and physical transformations, and wet and dry deposition to the earth. More than a decade later, we know that mercury cycling in the atmosphere is far more complex than earlier expectations. Today, areas of active study include mercury distribution, seasonality, and complex chemical transformations on the regional-to-global scale.

Mercury in the atmosphere consists of three operationally defined chemical forms including gaseous elemental mercury $\left(\mathrm{Hg}^{0}\right)$, reactive gaseous mercury $\left(\mathrm{RGM}=\mathrm{HgCl}_{2}+\mathrm{HgBr}_{2}+\mathrm{HgOBr}+\ldots\right)$, and particulate phase mercury $\left(\mathrm{Hg}^{\mathrm{P}}\right) \cdot \mathrm{Hg}^{0}$ is the primary form of mercury emitted into the atmosphere from natural and anthropogenic sources. $\mathrm{Hg}^{0}$ is oxidized to produce $\mathrm{RGM}$ by reaction with many oxidants which include ozone $\left(\mathrm{O}_{3}\right)$ (Hall, 1995; Calvert and Lindberg, 2005), hydroxyl radicals (OH) (Sommar et al., 2001; Calvert and Lindberg, 2005), and halogen atoms (Holmes et al., 2006, 2010; Stephens et al., 2012). RGM can bind to particles to create $\mathrm{Hg}^{\mathrm{P}}$. Further, RGM can be reduced back to $\mathrm{Hg}^{0}$ by $\mathrm{SO}_{2}$ and sunlight (Lindberg and Stratton, 1998).

Very little is known about $\mathrm{Hg}^{\mathrm{P}}$ in comparison to $\mathrm{Hg}^{0}$ and RGM and even less is known about the size distribution of $\mathrm{Hg}^{\mathrm{P}}$ in the atmosphere. The following studies suggest that the majority of $\mathrm{Hg}^{\mathrm{P}}$ resides in smaller particles in the atmosphere, which can be transported long-range. Tsai et al. (2003) reported that, for an urban site in Taiwan, an average of $\sim 70 \% \mathrm{Hg}^{\mathrm{P}}$ in $\mathrm{PM}_{10}$ was found in $\mathrm{PM}_{2.5}$. Wang 


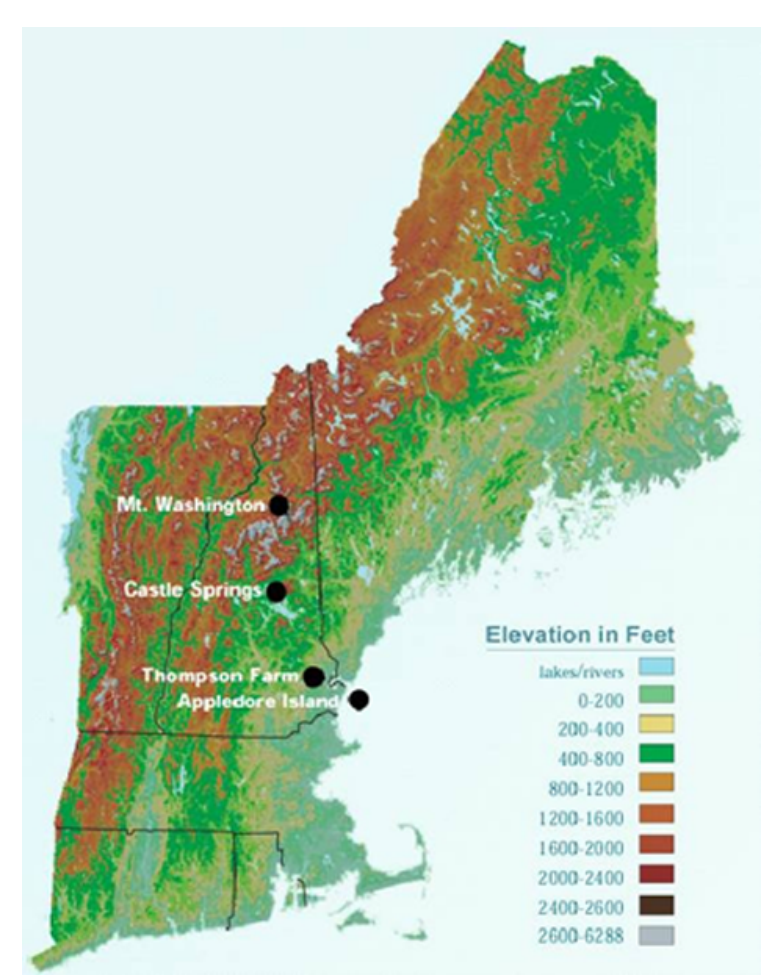

Fig. 1. Locations for the campaign: coastal site located at Thompson Farm in New Hampshire $\left(43.11^{\circ} \mathrm{N}, 70.95^{\circ} \mathrm{W}\right)$; marine site located in the Gulf of Maine on Appledore Island $\left(42.97^{\circ} \mathrm{N}, 70.62^{\circ} \mathrm{W}\right)$.

et al. (2006) studied two locations in Beijing, an urban and suburban site, reporting that both sites had the largest $\mathrm{Hg}^{\mathrm{P}}$ in $<1 \mu \mathrm{m}$ size fraction when measuring samples from $>7 \mu \mathrm{m}$ to $<1 \mu \mathrm{m}$. Xiu et al. (2009) studied size-fractionated total $\mathrm{Hg}^{\mathrm{P}}$ in urban, coastal Shanghai, China, at four size cut stages $(18,8.0,3.7,1.6 \mu \mathrm{m})$ and an after filter. Overall, there was more $\mathrm{Hg}^{\mathrm{P}}$ in winter, with the largest amount in the $<3.7 \mu \mathrm{m}$ range. Alvarez et al. (2004) analyzed various metals, including mercury, in 24 areas of Seville, Spain, an inland city along the River Guadalquivir. The maximum distribution of particles (accounting for $\sim 25 \%$ ) was between 0.6 and $4.9 \mu \mathrm{m}$. Keeler et al. (1995) measured $\mathrm{Hg}^{\mathrm{P}}$ in Detroit, $\mathrm{MI}$, and found the average distribution of fine particles at $0.68 \mu \mathrm{m}$ and course particles at $3.78 \mu \mathrm{m}$. Similarly, Gildemeister et al. (2005) collected $\mathrm{Hg}^{\mathrm{P}}$ in Detroit, MI, as fine particles $(<2.5 \mu \mathrm{m})$ and coarse $(>2.5 \mu \mathrm{m})$ and determined that the urban site had higher levels of $\mathrm{Hg}^{\mathrm{P}}$ than the rural site and additionally, the urban site had more coarse sized particles.

In this study, the size distribution of $\mathrm{Hg}^{\mathrm{P}}$ at a marine and a coastal site are compared. Ten size fractions were collected from $<0.4 \mu \mathrm{m}$ to $>10 \mu \mathrm{m}$ to evaluate dominant fractions at each site. Data was collected over one year and includes summer, winter and spring to determine the seasonal variability of $\mathrm{Hg}^{\mathrm{P}}$ size distributions in hopes of seeing a pattern of $\mathrm{Hg}^{\mathrm{P}}$ seasonality, not yet well defined. Urban and rural, subur- ban sites have been well studied for size distribution of $\mathrm{Hg}^{\mathrm{P}}$, however, data from marine locations has not been published. Data presented here is the first step in understanding the differences in marine $\mathrm{Hg}^{\mathrm{P}}$ with contributions from sea salt and open ocean air and coastal $\mathrm{Hg}^{\mathrm{P}}$ with effects from trees and rural pollution. Results show where $\mathrm{Hg}^{\mathrm{P}}$ resides in these two atmospheres and what influences the distribution during each season.

The benefit of our location was the ability to collect and compare particulate data from both a marine and a coastal site in the "tailpipe" of the United States. The GEOS-Chem model indicates that anthropogenic US emissions account for $13-23 \%$ of mercury deposition in the Northeast (Zhang et al.) and Driscoll et al. (2007) suggest that most of that deposited mercury will reemit into the atmosphere. At these sites, $\mathrm{Hg}^{\mathrm{P}}$ is expected to dominate the fractions correlating to sea salt aerosols $(1-6 \mu \mathrm{m})$ formed from bursting bubbles and waves breaking, which can affect areas up to $25 \mathrm{~km}$ from the coastline (De Leeuw et al., 2000; Athanasopoulou et al., 2008), dust particles, and/or ultrafine and accumulation particles $(<2 \mu \mathrm{m})$ emitted directly from combustion sources and resulting from coagulation of small particles (Finlayson-Pitts and Pitts, 2000).

\section{Campaign details}

Thompson Farm and Appledore Island are part of the AIRMAP observing network (www.airmap.unh.edu). The benefit of conducting these campaigns at both a marine and an inland, coastal site is to ascertain differences and similarities in the phase partitioning and cycling in the two atmospheres. The marine site is located in the Gulf of Maine on Appledore Island $\left(42.97^{\circ} \mathrm{N}, 70.62^{\circ} \mathrm{W}\right)$ about $12 \mathrm{~km}$ offshore from New Hampshire, Fig. 1. The inland site is located at Thompson Farm in coastal New Hampshire $\left(43.11^{\circ} \mathrm{N}\right.$, $70.95^{\circ} \mathrm{W}$ ) which is located about $25 \mathrm{~km}$ inland. A detailed description of the Thompson Farm site can be found in Sigler et al. (2009).

Six aerosol sampling campaigns were conducted at Thompson Farm and Appledore Island as part of a study on the cycling of mercury in the marine boundary layer. There were several objectives of the campaigns: (1) to quantify total and size-fractioned $\mathrm{Hg}^{\mathrm{P}}$; (2) compare and contrast the marine and coastal site for distribution of $\mathrm{Hg}^{\mathrm{P}}$; and (3) determine the importance of the size distribution of $\mathrm{Hg}^{\mathrm{P}}$ in the marine boundary layer.

During the summer of 2009, an intensive two week campaign was conducted on Appledore Island from 20 July4 August. Two cascade impactors were operated consecutively, each with a seven day time resolution. Bulk filter samples were also collected with three hour time resolution, and trace gases (hydrocarbons, halocarbons) were collected in electropolished stainless steel canisters every hour, additionally, during the summer campaigns a GCMS was used at 
Table 1. Sampling Details for $\mathrm{Hg}^{\mathrm{P}}$.

\begin{tabular}{|c|c|c|c|}
\hline Season & Dates & Location & Sample Type - Time Resolution \\
\hline \multirow[t]{3}{*}{ Summer 2009} & $20 \mathrm{Jul}-4$ Aug & Appledore Island & $\begin{array}{l}\text { Bulk Filters }-3 \mathrm{~h} \\
\text { Impactor }-7 \text { days } \\
\text { Tekran }-3 \mathrm{~h}\end{array}$ \\
\hline & 7 Aug-18 Aug & Thompson Farm & $\begin{array}{l}\text { Impactor }-11 \text { days } \\
\text { Tekran }-3 \mathrm{~h}\end{array}$ \\
\hline & 20 Aug-2 Sep & Appledore Island & $\begin{array}{l}\text { Impactor }-13 \text { days } \\
\text { Tekran }-3 \mathrm{~h}\end{array}$ \\
\hline Winter 2010 & $21 \mathrm{Jan}-10 \mathrm{Feb}$ & Thompson Farm & $\begin{array}{l}\text { Bulk Filters }-24 \mathrm{~h} \\
\text { Impactor }-10 \text { days } \\
\text { Tekran }-3 \mathrm{~h}\end{array}$ \\
\hline Spring 2010 & 5 Apr-25 Apr & Thompson Farm & $\begin{array}{l}\text { Bulk Filter }-24 \mathrm{~h} \\
\text { Impactor }-10 \text { days } \\
\text { Tekran }-3 \mathrm{~h}\end{array}$ \\
\hline \multirow[t]{2}{*}{ Summer 2010} & 26 Jul-9 Aug & Appledore Island & $\begin{array}{l}\text { Bulk Filter }-3 \mathrm{~h} \\
\text { Impactor }-7 \text { days } \\
\text { Tekran }-3 \mathrm{~h}\end{array}$ \\
\hline & 26 Jul-9 Aug & Thompson Farm & $\begin{array}{l}\text { Bulk Filter }-3 \mathrm{~h} \\
\text { Impactor }-7 \text { days } \\
\text { Tekran }-3 \mathrm{~h}\end{array}$ \\
\hline
\end{tabular}

Table 2. Andersen Mark II Cascade Impactor Size Distribution.

\begin{tabular}{ll}
\hline Pre-Separator & $>10 \mu \mathrm{m}$ \\
Stage 0 & $9.0-10.0 \mu \mathrm{m}$ \\
Stage 1 & $5.8-9.0 \mu \mathrm{m}$ \\
Stage 2 & $4.7-5.8 \mu \mathrm{m}$ \\
Stage 3 & $3.3-4.7 \mu \mathrm{m}$ \\
Stage 4 & $2.1-3.3 \mu \mathrm{m}$ \\
Stage 5 & $1.1-2.1 \mu \mathrm{m}$ \\
Stage 6 & $0.7-1.1 \mu \mathrm{m}$ \\
Stage 7 & $0.4-0.7 \mu \mathrm{m}$ \\
Backup Filter & $<0.4 \mu \mathrm{m}$
\end{tabular}

Thompson Farm and a PTRMS was used at Appledore Island to detect various other trace gases (isoprene, dimethyl sulfide (DMS)). Detection of trace gases aided in determining sources of air parcels, for example, isoprene is a tracer of biogenic and continental emissions, while tetrachloroethylene $\left(\mathrm{C}_{2} \mathrm{Cl}_{4}\right)$ is a tracer of urban sources, and bromoform $\left(\mathrm{CHBr}_{3}\right)$ and DMS indicate a marine source. Analysis of the canisters was conducted in the trace gas laboratory at the University of New Hampshire. Automated Tekran speciated atmospheric mercury systems, with $5 \mathrm{~min}$ time resolution for $\mathrm{Hg}^{0}$ and $3 \mathrm{~h}$ for $\mathrm{Hg}^{\mathrm{P}}$ and $\mathrm{RGM}$, were operated continuously at each site along with ozone and carbon monoxide with one minute time resolution. Details of each campaign are listed in Table 1.

Following the Appledore Island campaign, a second was conducted at Thompson Farm (7-18 August). The campaign consisted of two cascade impactors operated simultaneously for eleven days to determine the consistency in the $\mathrm{Hg}^{\mathrm{P}}$ size distribution. At Thompson Farm, trace gases are measured year-round including oxygenated compounds measured with a PTRMS.

Finally, in the summer of 2009, a third campaign was run at Appledore Island (20 August-2 September). The campaign lasted a total of thirteen days. One impactor was run $12 \mathrm{~h}$ during the day (06:00 a.m.-06:00 p.m. local time) and the other run for $12 \mathrm{~h}$ every night. The campaign was conducted to investigate the difference between day and night phase partitioning and cycling of $\mathrm{Hg}^{\mathrm{P}}$.

Two more campaigns were conducted at Thompson Farm in the winter (21 January-10 February) and spring (525 April) 2010, times of peak concentration of mercury in the New England atmosphere (Mao et al., 2008; Sigler et al., 2009; Lombard et al., 2011). During both campaigns, the cascade impactors were run consecutively for ten days each having a campaign lasting a total of twenty days. Bulk filter samples were run with $24 \mathrm{~h}$ resolution. Concurrently, a continuous gas chromatograph was set up to measure trace gases. This complete dataset allowed for determination of the seasonality of the size distribution of $\mathrm{Hg}^{\mathrm{P}}$ at the coastal site.

Finally, in the summer of 2010, two intensive campaigns were run simultaneously at both Thompson Farm and Appledore Island (26 July-9 August). The time resolution matched the first campaign at Appledore Island with two impactors at each site running consecutively for 7 days each and bulk filters at three hour time resolution. At Appledore Island, hourly canisters were collected; while at Thompson Farm, a continuous gas chromatograph analyzed trace gases. This 

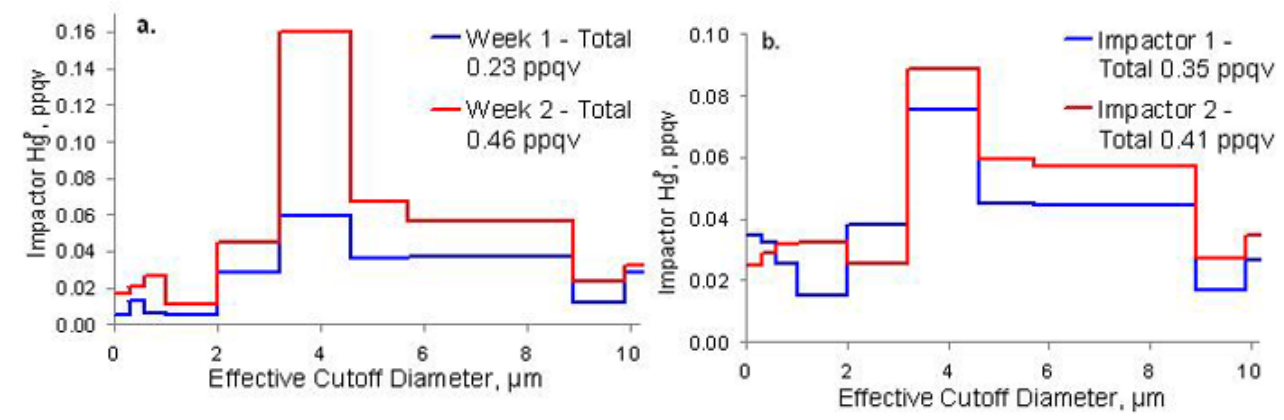

Fig. 2. Size Distribution of $\mathrm{Hg}^{\mathrm{P}}$ at Appledore Island (a) and Thompson Farm (b) for summer 2009 showing similar total $\mathrm{Hg}^{\mathrm{P}}$ at both sites with enhanced levels of coarse size fractions.

final addition allowed for comparison of the two summer sets of size distribution of $\mathrm{Hg}^{\mathrm{P}}$, as well as direct comparison between the marine and coastal sites.

\section{Methods}

Sampling at Thompson Farm is $40 \mathrm{~m}$ above sea level at the top of a steel tower located just above the tree line. Sampling at Appledore Island is located $30 \mathrm{~m}$ above sea level at the top of a World War II lookout tower. AIRMAP has been collecting $\mathrm{Hg}^{0}$ measurements at Thompson Farm since November 2003 and Appledore Island since July 2005 (Mao et al., 2008). During intensive field campaigns performed during summer 2009, winter 2010, spring 2010, and summer 2010, $\mathrm{Hg}^{\mathrm{P}}$ was measured using three different methods: bulk filter $\mathrm{Hg}^{\mathrm{P}}$, size-fractionated $\mathrm{Hg}^{\mathrm{P}}$, and $\mathrm{Hg}^{\mathrm{P}}$ with a Tekran model 1135. More detailed results on the comparison of the bulk filter samples and the Tekran model 1135 were published previously (Talbot et al., 2011).

The cascade impactors were Andersen Mark II Cascade Impactors with 10 filters, including a pre-filter and backup filter, capable of differentiating size distributions ranging from $<0.4 \mu \mathrm{m}$ to $>10 \mu \mathrm{m}$ (Table 2; discontinued, a similar model Series 20-800 eight stage non-viable impactor available from ThermoFisher Scientific Inc.). Millipore fluoropore filters of $90 \mathrm{~mm}$ diameter and $1 \mu \mathrm{m}$ pore size were used for the impactor as well as the bulk sample filters. The filters were pre-cleaned in $12 \mathrm{~h}$ acid soaks of $30 \% \mathrm{HNO}_{3}$ and $20 \% \mathrm{HCl}$ each. Blank filters went through the same handling process. For sampling the filters were placed in custom delrin holders and ambient air flowed through at $\sim 120$ standard liters per minute. The holders were washed with soapy de-ionized water and then soaked $12 \mathrm{~h}$ in $5 \% \mathrm{HCl}$. Samples and blanks were stored in clean room bags. Filter extractions were conducted using $1.5 \% \mathrm{BrCl}$ and $\mathrm{HCl}$ for $24 \mathrm{~h}$. They were then diluted to $0.5 \% \mathrm{BrCl}$ and $\mathrm{HCl}$ for analysis. Acid extracts were stored in Teflon bottles that were soaked $12 \mathrm{~h}$ in $50 \% \mathrm{HNO}_{3}$, another $12 \mathrm{~h}$ in $30 \% \mathrm{HCl}$, and finally soaked for 5 days in $5 \% \mathrm{HCl}$. The average blank filter contained
$25 \mathrm{pg}$ of $\mathrm{Hg}$, subtracted from the samples, which contained 10-100 times more Hg. Thus, the blank corrections were essentially in the background noise and contributed little to the overall uncertainty of the ambient measurements. It has been shown previously that filter methods have artifacts associated with the adsorption of RGM onto the particulates (Landis et al., 2002) or the loss of mercury when sampling times are greater than a few hours (Malcolm and Keeler, 2007). However, when tested in the laboratory, there was no loss of RGM to blank filters detected using the automated system. Any loss of mercury is assumed to be the same for each impactor and each size fraction, confirmed by results that were expected and easily explained by outside factors, for example, trace gas data or source of air parcel.

Analysis of these samples for $\mathrm{Hg}^{0}$ was via cold vapor atomic fluorescence using a Tekran Series 2600 Liquid Analysis System with $\mathrm{SnCl}_{2}$ as a reducing agent. Calibration standards were prepared from a $1000 \mathrm{ppm} \mathrm{HgO}$ in $3 \% \mathrm{HNO}_{3}$ Atomic Absorption solution purchased from Ricca Chemical Company. A certified reference material, ORMS-4 (Hg in water), purchased from the National Research Council Canada was utilized as an external standard. The accuracy of the instrument using the external standard was $<10 \%$. The analytical precision of repeated determinations of the ambient samples was better than $5 \%$.

\section{Campaign results and discussion}

In summer 2009, $\mathrm{Hg}^{\mathrm{P}}$ was found in coarse particles $>1.1 \mu \mathrm{m}$ at Appledore Island (Fig. 2a). The coarse aerosols are attributed primarily to sea salt particles. Sea salt aerosols can have diameters in a range of sizes from $0.2 \mu \mathrm{m}$ (fine) to more than $2000 \mu \mathrm{m}$ (coarse) (Athanasopoulou et al., 2008). The majority of sea salt aerosols are in the $1-10 \mu \mathrm{m}$ range. Sodium and chloride, making up $85 \%$ of elements in sea salt aerosols, have peak diameters around $4 \mu \mathrm{m}$ (Wall et al., 1988; Athanasopoulou et al., 2008; Finlayson-Pitts and Pitts, 2000). In the data set shown in Fig. 2a, about $60 \%$ of the summer data is from sea salt, in the range of $1.1-5.8 \mu \mathrm{m} . \mathrm{Hg}^{\mathrm{P}}$ 


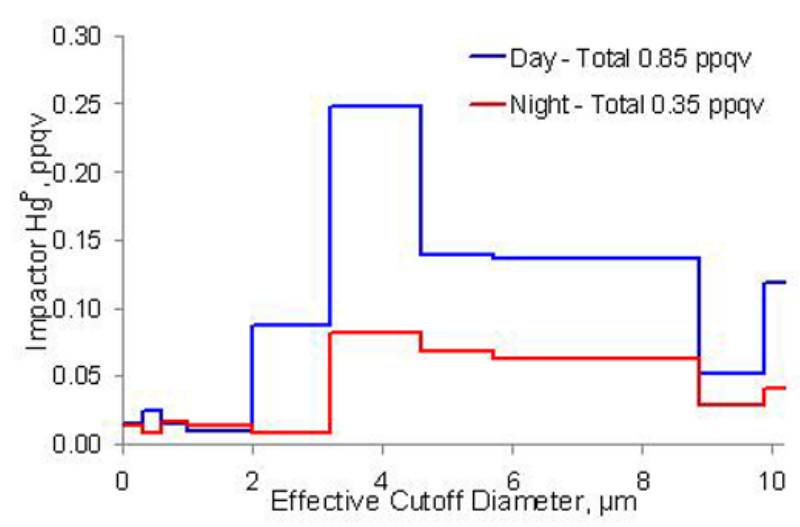

Fig. 3. Diurnal Distribution of $\mathrm{Hg}^{\mathrm{P}}$ at Appledore Island in summer 2009. There is more than twice as much $\mathrm{Hg}^{\mathrm{P}}$ during the day, due to many variables including enhanced sea salt generation and more RGM production during sunny days.

results are reported as mixing ratios in parts per quadrillion by volume (ppqv), such that $1 \mathrm{ng} \mathrm{m}^{-3}$ is $112 \mathrm{ppqv} \mathrm{Hg}$. The first week had about half of the total $\mathrm{Hg}^{\mathrm{P}}$ than during the second week. It is noted that the first week was stormy and rained the majority of the time, while the second week was sunny and clear. Rain events scrub mercury from the atmosphere (Mao et al., 2012), thus lowering the amount sampled by the impactor.

The sensitivity of the two impactors was tested at Thompson Farm, where both were run simultaneously. The results are shown in Fig. 2b. There is a $15.8 \%$ difference between the two impactors, likely due to small differences between the two. The overall size distribution patterns are similar, giving confidence in our size distributions. The trends match well for sizes $>4 \mu \mathrm{m}$ with impactor 2 being consistently higher, however $<4 \mu \mathrm{m}$ shows more variability. While the differences here are small, this may reflect their ability to determine aerosol size distributions. Both Thompson Farm and Appledore Island showed similar total particulate mercury over the course of the campaigns during the summer, with both sites showing the majority of particles in the sea salt size range (50\% at Thompson Farm), which can exist up to $25 \mathrm{~km}$ inland (De Leeuw et al., 2000; Athanasopoulou et al., 2008).

During the initial campaign at Appledore Island, it appeared that there was a trend in daytime versus nighttime $\mathrm{Hg}^{\mathrm{P}}$ as indicated by data from the automated system. Therefore, another size distribution analysis was planned to quantify this effect. As shown in Fig. 3, large size fractions of $\mathrm{Hg}^{\mathrm{P}}$ dominate during daytime, showing more than twice as much total $\mathrm{Hg}^{\mathrm{P}}$ during daylight hours compared to nighttime (cycles from 10:00 UTC to 22:00 UTC). This could be attributed to many factors including more RGM production during sunny days and subsequently depositing RGM to the surface of particles to yield more $\mathrm{Hg}^{\mathrm{P}}$ during the day (Sigler et al., 2009)

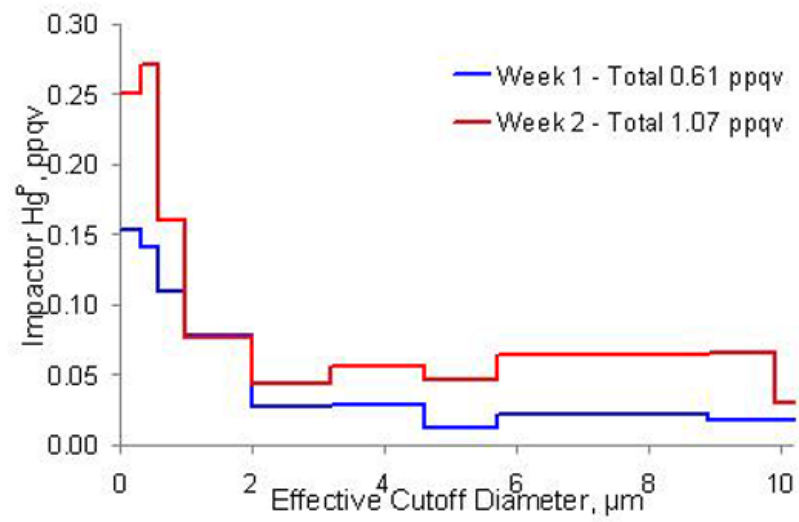

Fig. 4. Size Distribution of $\mathrm{Hg}^{\mathrm{P}}$ at Thompson Farm during winter 2010 showing the majority of $\mathrm{Hg}^{\mathrm{P}}$ in the fine particle range.

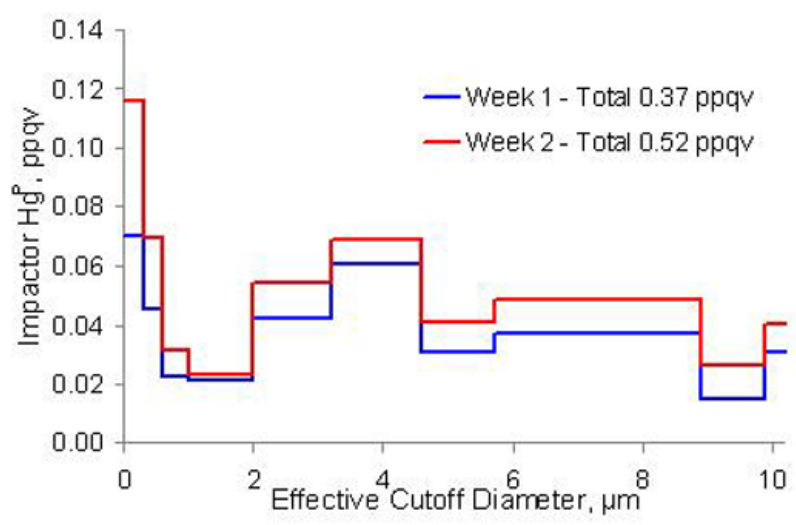

Fig. 5. Size Distribution of $\mathrm{Hg}^{\mathrm{P}}$ at Thompson Farm in spring 2010 which shows a distribution of fine and coarse size fractions.

as well as the possibility of enhanced sea salt generation during the day. In addition, a nocturnal inversion may be setting up cutting off tropospheric RGM to the site.

In winter at Thompson Farm, about $65 \%$ of the $\mathrm{Hg}^{\mathrm{P}}$ was found in fine particles $<1.1 \mu \mathrm{m}$ (Fig. 4). These fine particles are attributed to fine crustal dust, sulfate aerosols, organic matter, and soot particles commonly found at continental locations. Fine particles are high in winter and spring, consistent with increases in combustion sources related to wintertime heating and long-range transport (Jaffe et al., 2005; Weiss-Penzias et al., 2007; Xiu et al. 2009; Wang et al., 2006). The dominance of the fine particles may also be attributed to the fact that smaller particles are much less scavenged in the winter than the summer (Lombard et al., 2011). On average, there is more wet deposition in summer than in winter as shown in Lombard et al. (2011). More rain in the warm season scavenges more particles and leads to less $\mathrm{Hg}^{\mathrm{P}}$. The total $\mathrm{Hg}^{\mathrm{P}}$ observed during the winter is more than twice the total amount seen in summer and spring, confirming reports from Tsai et al. (2003) and Wang et al. (2006) who 

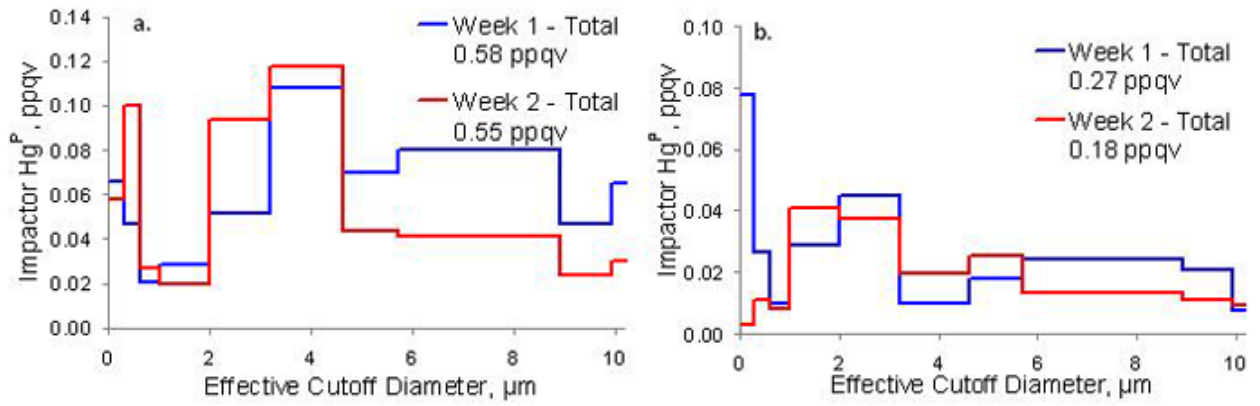

Fig. 6. Size Distribution of $\mathrm{Hg}^{\mathrm{P}}$ at Appledore Island (a) and Thompson Farm (b) during summer 2010 showing similar distributions of $\mathrm{Hg}^{\mathrm{P}}$ at both sites with Appledore Island exhibiting twice as much total $\mathrm{Hg}^{\mathrm{P}}$.
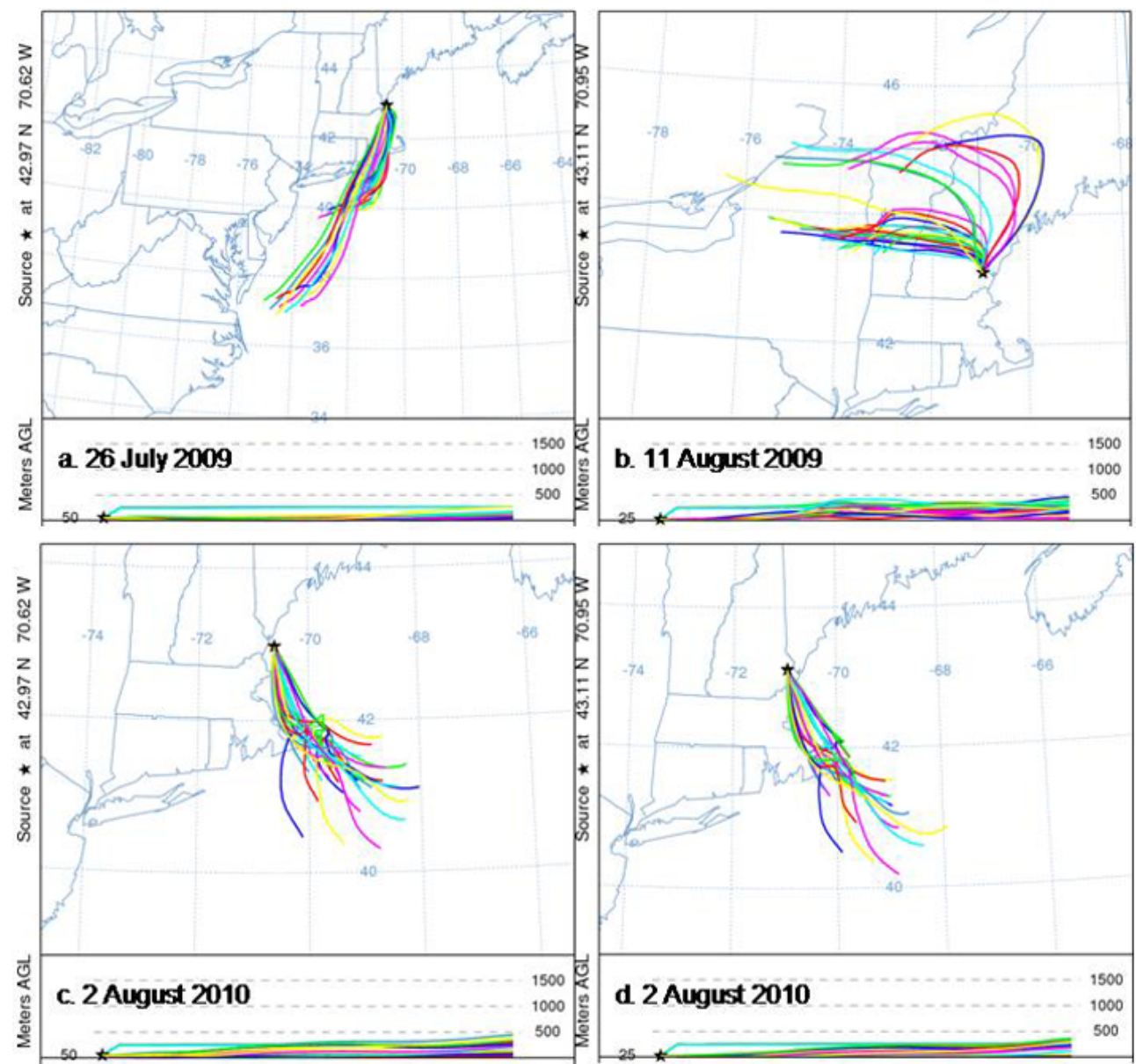

Fig. 7. HYSPLIT backward trajectories for Appledore Island ((a) 26 July 2009 and (c) 2 August 2010) and Thompson Farm ((b) 11 August 2009 and (d) 2 August 2010) showing different air parcels affecting the sites during 2009 and similar air parcels during 2010.

showed higher total $\mathrm{Hg}^{\mathrm{P}}$ in winter, resulting from a decline in mercury during the warm season due to the strength of the removal processes (Mao et al., 2008). In addition, westerly flow in winter combined with colder temperatures may advect more $\mathrm{Hg}^{\mathrm{P}}$ of continental origin, largely in fine particle size fractions, to the area than in summertime (Mao et al., 2008).

Generally, the peak concentration of mercury in the atmosphere in New England is in the springtime (Mao et al., 2008; Sigler et al., 2009; Lombard et al. 2011). It is believed that this occurrence is attributed to surface re-emission of 


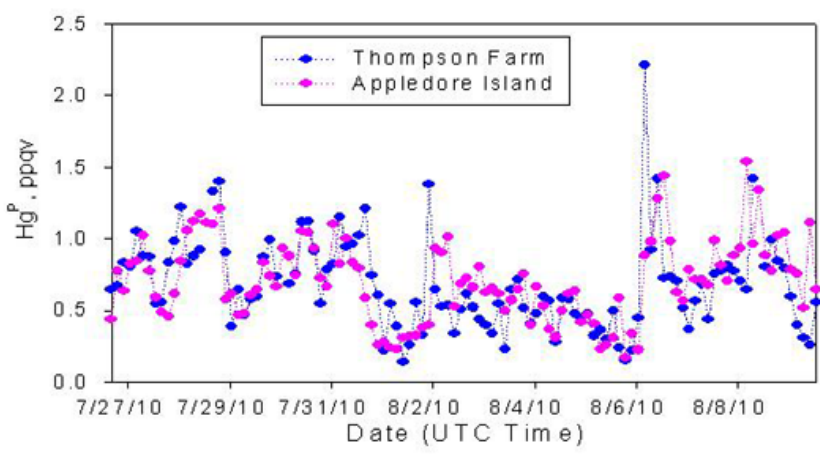

Fig. 8. Bulk filter data from summer 2010 at Thompson Farm (blue) and Appledore Island (pink) showing both sites track each other nicely as a result of similar sources of air masses as shown in Fig. 7. There are some discrepancies between the two locations; Thompson Farm has two outlying points which may be attributed to local interferences that affected Thompson Farm but not Appledore Island, such as fires and fog.

mercury during snow melt (Vanarsdale et al., 2005). However, the 2010 winter was warm, and snow was melting much earlier than April, which is probably why the winter campaign impactor contained more total $\mathrm{Hg}^{\mathrm{P}}$ than the spring impactor. The spring results (Fig. 5) showed a mixture of fine $(40 \%)$ and coarse (38\%) particles implying a transition from winter, which was dominated by the fine fraction, to summer, which includes marine influences with dominance by the coarse fraction.

The summer 2010 results are similar to those of the spring, showing both fine and coarse particles dominating $\mathrm{Hg}^{\mathrm{P}}$ at both sites (28\% fine particles, $47 \%$ coarse at Thompson Farm and 30\% fine, 50\% coarse at Appledore Island). Thompson Farm (Fig. 6b) had more of an influence from fine particles during the first week which may be attributed to the source of air. During the first week, the air masses originated from source regions to the north and west with primarily an influence of continental emissions as evidenced by the presence of isoprene and pinenes. In contrast, the second week was impacted by air masses originating from the south with a marine contribution. It is interesting to note that Appledore Island (Fig. 6a) had about twice as much total $\mathrm{Hg}^{\mathrm{P}}$ than Thompson Farm, especially in the sea salt region of the size distribution possibly due to the involvement of halogen chemistry in $\mathrm{Hg}$ cycling in the marine boundary layer such that more RGM is produced which then leads to more $\mathrm{Hg}^{\mathrm{P}}$ (Holmes et al., 2009; Mao et al., 2008; Hedgecock and Pirrone, 2001; Sigler et al., 2009). The distribution of fine and coarse particles at each location could reflect the influence of marine air, coarse particles, on coastal air, fine particles, and vice versa as shown in an earlier study in which Appledore Island is influenced by continental air about $14 \%$ of the time, while Thompson Farm is influenced by marine air about $30 \%$ of the time in summer (Chen et al., 2007).

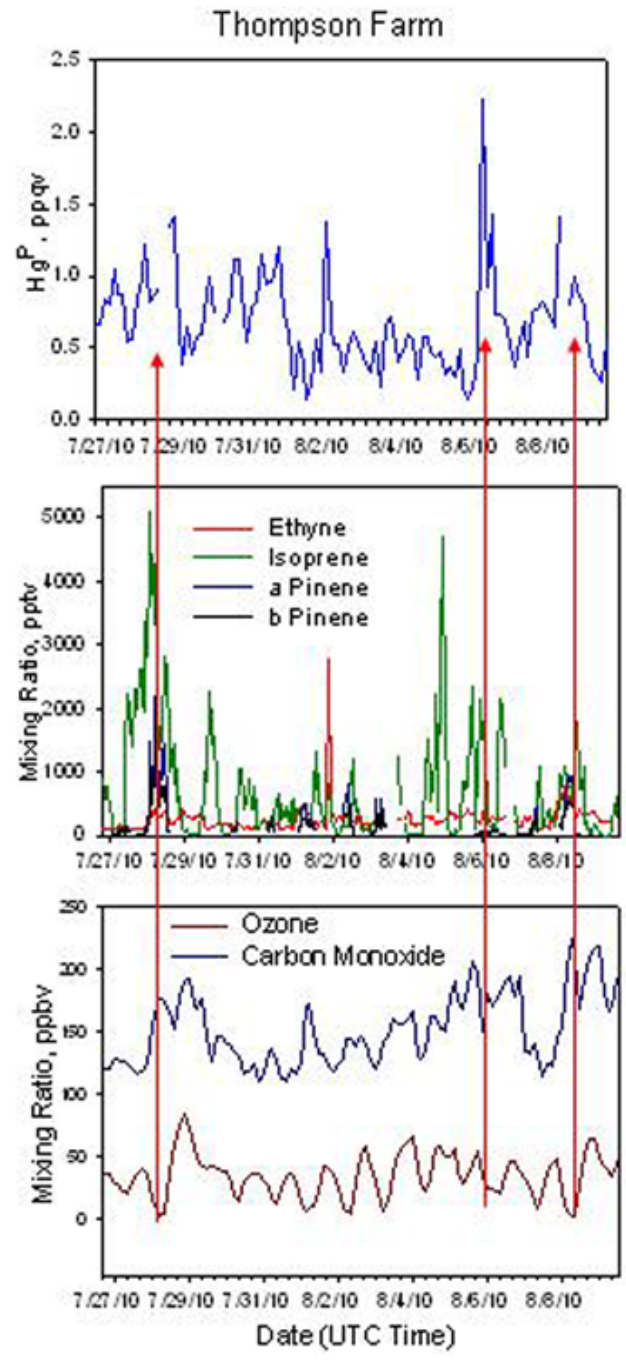

Fig. 9. Hydrocarbon data correlates with $\mathrm{Hg}^{\mathrm{P}}$ peaks shown for Thompson Farm. Top Panel: bulk filter data for Thompson Farm during summer 2010. Middle Panel: hydrocarbon data from GC showing ethyne (red), isoprene (green), $\alpha$-pinene (blue), and $\beta$ pinene (black) at one hour time resolution. Bottom Panel: ozone (red) and carbon monoxide (blue) data from Thompson Farm at one hour time resolution. Based on $\mathrm{CO}$ and $\mathrm{C}_{2} \mathrm{H}_{2}$, this is a relatively clean time period. Results show that peaks in hydrocarbon data and carbon monoxide indicate an increase in $\mathrm{Hg}^{\mathrm{P}}$ to the region. It also shows that $\mathrm{Hg}^{\mathrm{P}}$ has many sources, as shown by the elevation in some substances does not always indicate an elevation in $\mathrm{Hg}^{\mathrm{P}}$.

In comparing the Appledore Island impactors operated during both summers, it is clear that the marine site is heavily impacted by sea salt particles and that finer particles influenced the marine air more during the summer of 2010 which may be a result of many factors including source of the air masses (continental or marine origins), wind speed $\left(6.6 \mathrm{~m} \mathrm{~s}^{-1}\right.$ average speed in 2009 vs. $5.0 \mathrm{~m} \mathrm{~s}^{-1}$ average wind speed in 2010), and less rain (10.7 mm rain vs. $109.2 \mathrm{~mm}$ rain in 2009), allowing fine particles to travel farther. The amount 


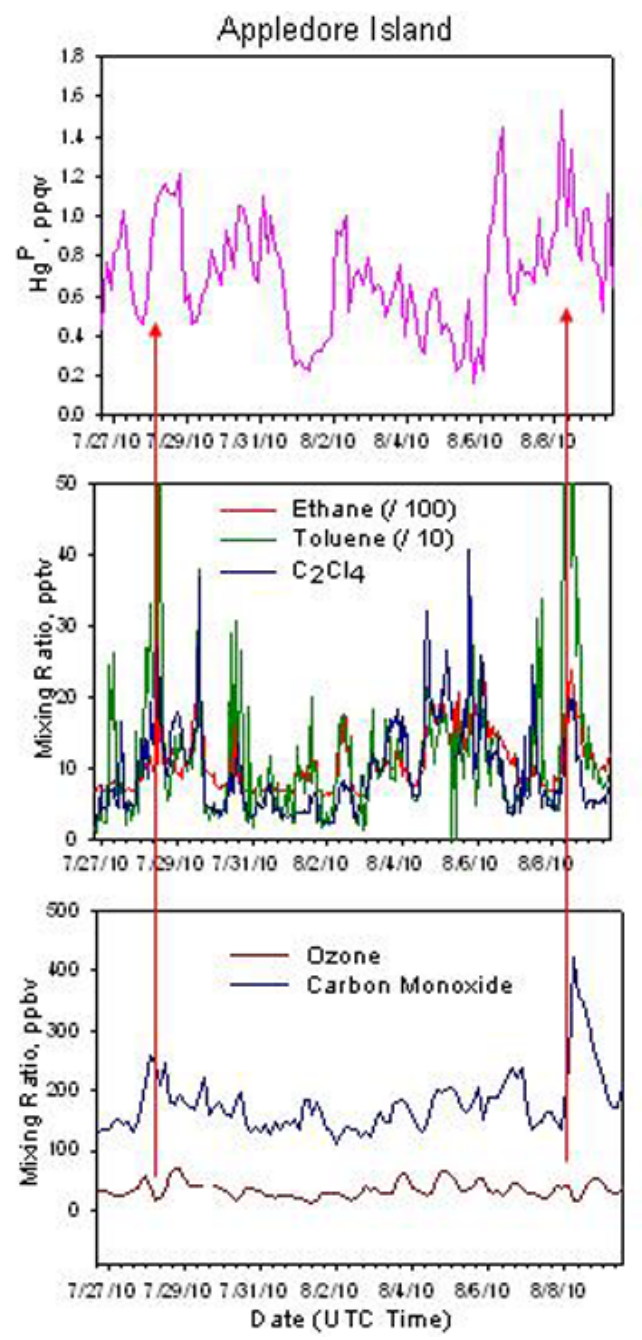

Fig. 10. Hydrocarbon data correlates with $\mathrm{Hg}^{\mathrm{P}}$ peaks shown for Appledore Island. Top Panel: bulk filter data for Appledore Island during summer 2010. Middle Panel: hydrocarbon data from hourly canister samples showing ethane (purple), toluene (green), and tetrachloroethylene (blue). Ethane values are graphed as a factor of 100 and toluene is a factor of 10 , at one hour time resolution. Bottom Panel: ozone (red) and carbon monoxide (blue) data from Appledore Island at one hour time resolution. The same is shown for Appledore Island, where peaks in different substances indicate elevation in $\mathrm{Hg}^{\mathrm{P}}$.

of total $\mathrm{Hg}^{\mathrm{P}}$ integrated over all size fractions was very similar for both summers, with the exception of the first week of summer 2009 where large amounts of precipitation scrubbed out the $\mathrm{Hg}^{\mathrm{P}}$. This implies that the difference in size distribution in the two summers did not affect the total $\operatorname{Hg}^{\mathrm{P}}$. This phenomenon is possibly because the marine site is dominated by larger particles contributing more to the mass which affects the total $\mathrm{Hg}^{\mathrm{P}}$ more than the fine particles.

Thompson Farm, during the two summers, also showed more fine particles in the summer of 2010 and more influence by marine air in summer 2009. Again, the total amount of $\mathrm{Hg}^{\mathrm{P}}$ is similar during both summers; however, there seems to be more variability in total $\mathrm{Hg}^{\mathrm{P}}$ at this site. $\mathrm{Hg}^{\mathrm{P}}$ is more particle size dependent at Thompson Farm than at Appledore Island, possibly because when larger sea salt particles reach the site, they greatly influence the total $\mathrm{Hg}^{\mathrm{P}}$ contributing more to the total mass.

The first summer campaign showed very different patterns between the marine and coastal sites, while the second summer campaign, conducted simultaneously at both sites, showed very similar trends in size distribution. Backward trajectories can help explain this occurrence. The Hybrid Single-Particle Lagrangian Integrated Trajectory (HYSPLIT) model was used (http://www.arl.noaa.gov). The trajectories were run for $24 \mathrm{~h}$ using the EDAS-40-km archive grid. Dates in mid-campaign show that during the first summer, Appledore Island was influenced by air coming from the south at the end of July, while Thompson Farm was influenced by air from the north in mid-August (Fig. 7a and b). This explains why the two campaigns exhibited different size distributions. However, during summer 2010, backward trajectories show that both sites were influenced by the same air parcels that originated from the southwest in early August (Fig. 7c and d) leading to similar size distributions. The difference in the patterns is thus attributed to the time difference between the campaigns.

The summer 2010 campaign also allowed for direct comparison of bulk filter data at Thompson Farm and Appledore Island. Details about the previous seasonal data can be found in Talbot et al. (2011). The bulk filters occasionally tracked each other $\left(r^{2}=0.3\right)$ with similar mixing ratios and general trends in elevated and reduced mixing ratios, as shown in Fig. 8. There are a couple discrepancies between the two sites; specifically, Thompson Farm has spikes in data which may be attributed to small differences in local events. Early on 2 August, a large peak occurred during the filter sampling following a smoke/fire smell in the area, with elevated $\mathrm{CO}$ at 170 ppbv. Smoke smells also occurred at Appledore Island on 1 August (CO at 183 ppbv) and 8 August (CO at 420 ppbv) due to fire on an adjacent island, $\sim 1 \mathrm{~km}$ away. The 6 August event at Thompson Farm occurred after a period of extreme fog.

Furthermore, peaks in $\mathrm{Hg}^{\mathrm{P}}$ coincide with enhancements in hydrocarbons in the atmosphere at both sites (Figs. 9 and 10). Tracer compounds include isoprene, a biogenic or continental emission tracer, and tetrachloroethylene, an urban emission tracer, $\mathrm{CO}, \mathrm{O}_{3}$, ethyne, and monoterpenes. $\mathrm{Hg}^{\mathrm{P}}$ peaks at Thompson Farm appear to associate with enhancements in carbon monoxide as well as biogenic species such as isoprene, $\alpha$-pinene, and $\beta$-pinene and Appledore Island peaks are associated with peaks in tetrachloroethylene suggesting a continental influence confirmed by trajectory patterns from the west which bring in air masses of continental origin.

Bulk filter results for summer 2010 also confirm a discrepancy with the Tekran measurements. There may be two possible explanations for the discrepancy. First, the Tekran 

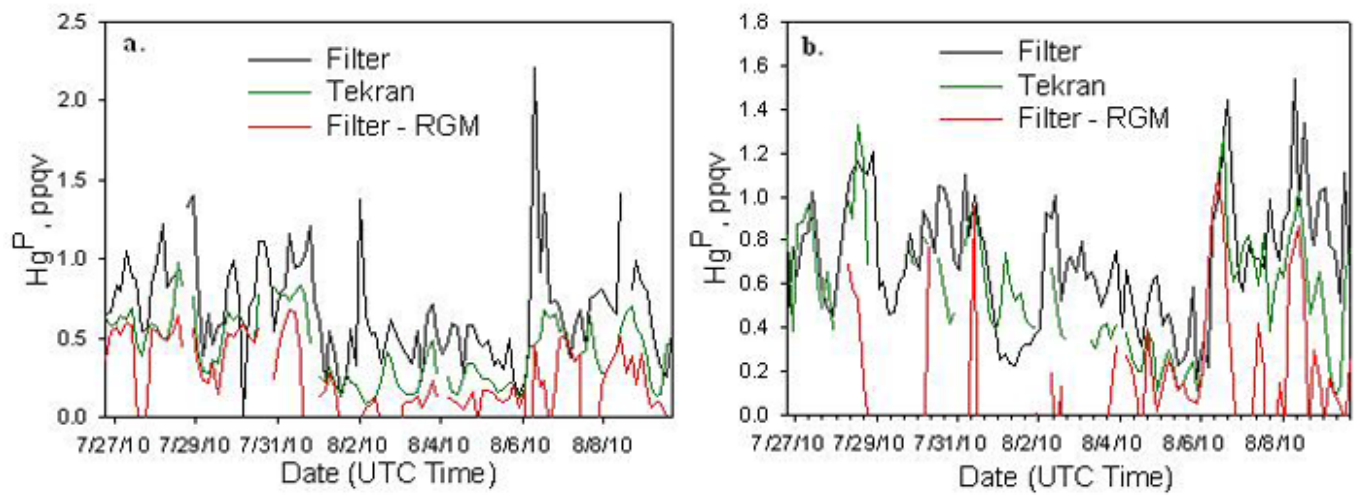

Fig. 11. Comparison of Tekran data (green) and bulk filter data (black) with filter-RGM data (red) from Thompson Farm (a) and Appledore Island (b). It appears that Thompson Farm may occasionally be affected by a RGM artifact as shown by the red data, while Appledore Island filters track the Tekran much better which may be a result of removal of the impactor on the Tekran at Appledore Island. It is still unclear if RGM affects $\mathrm{Hg}^{\mathrm{P}}$ measurements using filters.
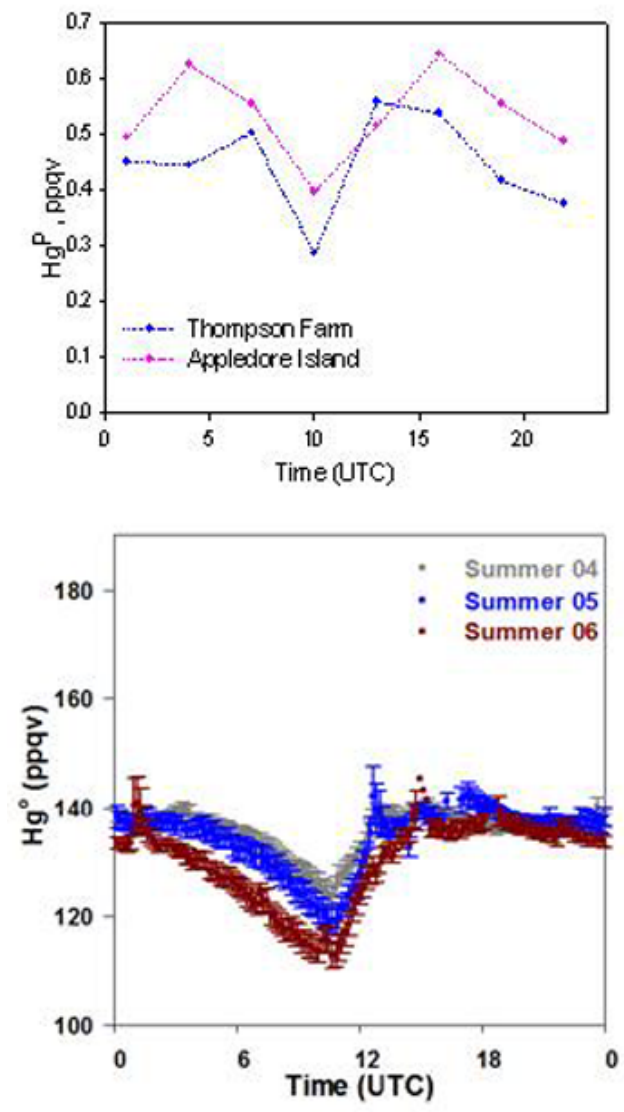

Fig. 12. Top Panel: diurnal cycle of $\mathrm{Hg}^{\mathrm{P}}$ at Thompson Farm (blue) and Appledore Island (pink) Bottom Panel: $\mathrm{Hg}^{0}$ diurnal cycle at Thompson Farm (Mao et al., 2008) (Note: noon local time is 16:00 UTC). Both sites show a minimum at night and maximum points just before and just after the minimum possibly due to nighttime chemical reactions and photochemical generation. may be less responsive to the enhancements in $\mathrm{Hg}^{\mathrm{P}}$ that were associated with enhancements in hydrocarbons shown in Figs. 9 and 10. This was shown in more detail for the previous summer, winter and spring data by Talbot et al. (2011). The difference in the summer measurements here may be due to a positive artifact $(50 \%)$ at Thompson Farm as evidenced by large peaks in filter $\mathrm{Hg}^{\mathrm{P}}$ possibly related to an RGM artifact (Fig. 11a). The figure shows the bulk filter $\mathrm{Hg}^{\mathrm{P}}$ in black, the Tekran $\mathrm{Hg}^{\mathrm{P}}$ in green, and the bulk filter $\mathrm{Hg}^{\mathrm{P}}$ minus the Tekran RGM in red. The green and red points correlate better than the black and green points $\left(r^{2}=0.6\right.$ vs. $\left.r^{2}=0.3\right)$, showing that RGM may contribute to a positive artifact on the filters at Thompson Farm. Landis et al. (2002) reported a significant RGM artifact on filters where $\mathrm{KCl}$-coated denuders were not used and RGM exceeded $15 \mathrm{pg} \mathrm{m}^{-3}$, conditions that rarely happen at either of our sites. It may also be due to the Tekran $\mathrm{PM}_{2.5}$ elutriator. It is evident that Thompson Farm is affected by larger particles (Fig. 2b), therefore, a significant amount of $\mathrm{Hg}^{\mathrm{P}}$ is not detected using the Tekran. However, there does not appear to be an artifact at Appledore Island as the filters and Tekran tracked each other better (Fig. 11b) $\left(r^{2}=0.4\right.$ vs. $r^{2}=0.1$ for filters and filter-RGM, respectively). This may be attributed to the removal of the $\mathrm{PM}_{2.5}$ elutriator on the Tekran inlet, which removes the majority of the particulate mercury at Appledore Island located in the larger sized fractions (Figs. 2a, 3, 6a). At Appledore Island, RGM does not appear to significantly contribute to bulk filter measurements of $\mathrm{Hg}^{\mathrm{P}}$, which agrees with studies done by Malcolm and Keeler (2007) and Talbot et al. (2011) who showed that RGM does not always contribute artifacts. RGM at Appledore Island during this summer was at much higher concentrations than at Thompson Farm, while $\mathrm{Hg}^{\mathrm{P}}$ is at similar concentrations at each site. RGM may be contributing at Appledore Island to some extent (41\%), but high levels of RGM do not seem to indicate more interference. 
The seasonality of the bulk filter data at Thompson Farm shows that spring has relatively constant levels of $\mathrm{Hg}^{\mathrm{P}}$, while winter and summer show more variability with increased levels and more pollution events (Talbot et al., 2011). In addition, the bulk filters showed a diurnal cycle that matches that of elemental mercury (Fig. 12), as reported by Mao et al. (2008) for summer. Xiu et al. (2009) and Liu et al. (2007) recorded similar results showing a diurnal pattern with a peak in the early morning hours closely related to the diurnal pattern of $\mathrm{Hg}^{0}$. Both the marine and coastal sites show similar times of depletion, with a pattern most likely due to nighttime removal pathways and the nocturnal inversion layer. There was a peak in $\mathrm{Hg}^{\mathrm{P}}$ just before and after the depletion suggesting enhancement in $\mathrm{Hg}^{\mathrm{P}}$ due to generation by nighttime chemical reactions and daytime photochemical reactions. The latter is corroborated by the pattern of enhanced RGM during the daytime from mixing and photochemically induced reactions, such that enhanced RGM leads to enhanced $\mathrm{Hg}^{\mathrm{P}}$ (Tsai et al., 2003). There is little information about nighttime chemical reactions involving mercury, but it has been reported that there could be dissolution of $\mathrm{Hg}^{0}$ directly into the aerosol in the nocturnal inversion layer without oxidation to RGM (Kim, 2010). The fact that there is a cycle and that both $\mathrm{Hg}^{\mathrm{P}}$ diurnal cycles resemble that of $\mathrm{Hg}^{0}$ signifies the presence of the inversion layer at these sites. More data are needed to confirm the diurnal pattern seen here.

The data was used to calculate $\mathrm{Hg}^{\mathrm{P}}$ dry deposition rates. Rates were calculated to be $1.7 \mathrm{ng} \mathrm{m}^{-2}$ day $^{-1}$ in summer, $4.6 \mathrm{ng} \mathrm{m}^{-2}$ day $^{-1}$ in winter, and $2.5 \mathrm{ng} \mathrm{m}^{-2} \mathrm{day}^{-1}$ in spring at Thompson Farm and $2.8 \mathrm{ng} \mathrm{m}^{-2}$ day $^{-1}$ in summer at Appledore Island. The flux is the product of the atmospheric concentration and the average deposition velocity of $\mathrm{Hg}^{\mathrm{P}}$, $0.5 \mathrm{~cm} \mathrm{~s}^{-1}$ (Landis and Keeler, 2002). There is more deposition at Appledore Island during the summer than at Thompson Farm, due to the large portion of $\mathrm{Hg}^{\mathrm{P}}$ in sea salt sized particles. Thompson Farm results show the seasonality of the deposition, with the most dry deposition occurring during the winter; it has been shown that the most extensive $\mathrm{Hg}^{\mathrm{P}}$ deposition occurs during the winter months (Wang et al., 2006). Averaging the seasons, Thompson Farm shows an annual deposition rate of $1.1 \mathrm{\mu g} \mathrm{m}^{-2} \mathrm{yr}^{-1}$ similar to Reinfelder et al. (2004) who reported $\mathrm{Hg}^{\mathrm{P}}$ deposition rates at several locations in New Jersey ranging from $0.8-2.5 \mu \mathrm{g} \mathrm{m}^{-2} \mathrm{yr}^{-1}$ and Landis and Keeler (2002) who reported an $\mathrm{Hg}^{\mathrm{P}}$ deposition flux of $1.2 \mu \mathrm{g} \mathrm{m}^{-2} \mathrm{yr}^{-1}$ in the Lake Michigan basin. Thompson Farm seasonal results, however, show that yearly data must be taken into account and annually averages cannot be factored using just one season of data.

\section{Conclusions}

A study was conducted to evaluate the size distribution and seasonality of atmospheric particulate mercury in marine and coastal atmospheres. It was determined that the aerosol size distribution and amount of total $\mathrm{Hg}^{\mathrm{P}}$ is influenced by location (marine or coastal), precipitation and wind speed, and trajectory of source air. The marine site is dominated by larger sea salt sized $\mathrm{Hg}^{\mathrm{P}}$, while the coastal site is influenced by smaller sized $\mathrm{Hg}^{\mathrm{P}}$. The coastal and marine sites are in close enough proximity that they are often affected by the same source of air. Further, a diurnal cycle of $\mathrm{Hg}^{\mathrm{P}}$ is shown that matches that of $\mathrm{Hg}^{0}$. Dry deposition of $\mathrm{Hg}^{\mathrm{P}}$ is calculated for each season, showing that winter has the highest removal rates.

Acknowledgements. We appreciate the logistical support provided by the Shoals Marine Laboratory on Appledore Island, sampling assistance from Jennie Garcia, sample preparation and editing assistance from Melissa Lombard and field assistance from Kevan Carpenter. Financial support was obtained from the National Science Foundation under grant \#NSF114173, the National Oceanic and Atmospheric Administration AIRMAP program under grant \#NA07OAR4600514, the Environmental Protection Agency under contract \#EP09H000355, and the National Aeronautics and Space Administration Graduate Student Researchers Program Fellowship under grant \#NNX10AM50H.

Edited by: A. Dastoor

\section{References}

Alvarez, F. F., Rodriguez, M. T., Espinosa, A. J. F., and Daban, A. G.: Physical speciation of arsenic, mercury, lead, cadmium and nickel in inhalable atmospheric particles, Anal. Chim. Acta, 524, 33-40, 2004.

Athanasopoulou, E., Tombrou, M., Pandis, S. N., and Russell, A. G.: The role of sea-salt emissions and heterogeneous chemistry in the air quality of polluted coastal areas, Atmos. Chem. Phys., 8, 5755-5769, doi:10.5194/acp-8-5755-2008, 2008.

Calvert, J. G. and Lindberg, S. E.: Mechanisms of mercury removal by $\mathrm{O}_{3}$ and $\mathrm{OH}$ in the atmosphere, Atmos. Environ., 139, 33553367, 2005.

Chen, M., Talbot, R., Mao, H., Sive, B., Chen, J., and Griffin, R. J.: Air mass classification in coastal New England and its relationship to meterological conditions, J. Geophys. Res., 112, D10S05, doi:10.1029/2006JD007687, 2007.

De Leeuw, G., Neele, F. P., Hill, M., Smith, M. H., and Vignati, E.: Production of sea spray aerosol in the surf zone, J. Geophys. Res., 105, 29397-29410, 2000.

Driscoll, C. T., Han, Y.-J., Chen, C. Y., Evers, D. C., Lambert, K. F., Holsen, T. M., Kamman, N. C., and Munson, R. K.: Mercury contamination in forest and freshwater ecosystems in the Northeastern United States, Bioscience, 57, 17-28, 2007.

Finlayson-Pitts, B. J. and Pitts Jr., J. N.: Chemistry of the Upper and Lower Atmosphere, Academic Press, San Diego, CA, USA, 383 pp., 2000.

Gildemeister, A. E., Graney, J., and Keeler, G. J.: Source proximity reflected in spatial and temporal variability in particle and vapor phase mercury concentration in Detroit, Mi., Atmos. Environ., 39, 353-358, 2005.

Hall, B.: The gas-phase oxidation of elemental mercury by ozone, Water Air Soil Pollut., 80, 301-315, 1995. 
Hedgecock, I. M. and Pirrone, N.: Mercury and photochemistry in the marine boundary layer-modelling studies suggest the in situ production of reactive gas phase mercury, Atmos. Environ., 35, 3055-3062, 2001.

Holmes, C. D., Jacob, D. J., and Yong, X.: Golbal Lifetime of elemental mercury against oxidation by atomic bromine in the free troposphere, Geophys. Res. Lett., 33, L20808, doi:10.1029/2006GL027176, 2006.

Holmes, C. D., Jacob, D. J., Mason, R. P., and Jaffe, D. A.: Sources and deposition of reactive gaseous mercury in the marine atmosphere, Atmos. Environ., 43, 2278-2285, 2009.

Holmes, C. D., Jacob, D. J., Corbitt, E. S., Mao, J., Yang, X., Talbot, R., and Slemr, F.: Global atmospheric model for mercury including oxidation by bromine atoms, Atmos. Chem. Phys., 10, 12037-12057, doi:10.5194/acp-10-12037-2010, 2010.

Jaffe, D., Prestbo, E., Swartzendruber, P., Weiss-Penzias, P., Kato, S., Takami, A., Hatakeyama, S., and Kajii, Y.: Export of atmospheric mercury from Asia, Atmos. Environ., 39, 3029-3038, 2005.

Keeler, G. J., Glinsorn, G., and Pirrone, N.: Particulate mercury in the atmosphere: It's significance, transport, transformation, and sources, Water Air Soil Pollut., 80, 159-168, 1995.

Kim, S. Y.: Continental outflow of polluted air from the US to the North Atlantic and mercury cycling in various atmospheric environments, Ph.D. dissertation, University of New Hampshire, 114 pp., 2010.

Landis, M. S. and Keeler, G. J.: Atmospheric mercury deposition to Lake Michigan during the Lake Michigan mass balance study, Environ. Sci. Technol., 36, 4518-4524, 2002.

Landis, M. S., Stevens, R. K., Schaedlich, F., and Prestbo, E. M.: Development and characterization of an annular denuder methodology for the measurement of divalent inorganic reactive gaseous mercury in ambient air, Environ. Sci. Technol., 36, 3000-3009, 2002.

Lindberg, S. E. and Stratton, W. J.: Atmospheric mercury specitation: Concentrations and behavior of reactive gaseous mercury in ambient air, Environ. Sci. Technol., 32, 49-57, 1998.

Liu, B., Keeler, G. J., Dvonch, J. T., Barres, J. A., Lynam, M. M., Marsik, F. J., and Morgan, J. T.: Temporal variability of mercury speciation in urban air, Atmos. Environ., 41, 1911-1923, 2007.

Lombard, M. A. S., Bryce, J. G., Mao, H., and Talbot, R.: Mercury deposition in Southern New Hampshire, 2006-2009, Atmos. Chem. Phys., 11, 7657-7668, doi:10.5194/acp-11-76572011, 2011.

Malcolm, E. G. and Keeler, G. J.: Evidence for a sampling artifact for particulate phase mercury in the marine atmosphere, Atmos. Environ., 41, 3352-3359, 2007.

Mao, H., Talbot, R. W., Sigler, J. M., Sive, B. C., and Hegarty, J. D.: Seasonal and diurnal variations of $\mathrm{Hg}^{0}$ over New England, Atmos. Chem. Phys., 8, 1403-1421, doi:10.5194/acp-8-1403-2008, 2008.

Mao, H., Talbot, R., Hegarty, J., and Koermer, J.: Speciated mercury at marine, coastal, and inland sites in New England - Part 2: Relationships with atmospheric physical parameters, Atmos. Chem. Phys., 12, 4181-4206, doi:10.5194/acp-12-4181-2012, 2012.
Reinfelder, J. R., Totten, L. A., and Eisenreich, S. J.: The New Jersey Atmospheric Deposition Network: Final Report to the New Jersey Department of Environmental Protection, Rutgers University, New Brunswick, NJ, 160 pp., 2004.

Schroeder, W. H. and Munthe, J.: Atmospheric Mercury - An Overview, Atmos. Environ., 32, 809-822, 1998.

Sigler, J. M., Mao, H., and Talbot, R.: Gaseous elemental and reactive mercury in Southern New Hampshire, Atmos. Chem. Phys., 9, 1929-1942, doi:10.5194/acp-9-1929-2009, 2009.

Sommar, J., Gardfeldt, K., Stromberg, D., and Feng, X. B.: A kinetic study of the gas-phase reaction between the hydroxyl radical and atomic mercury, Atmos. Environ., 35, 3049-3054, 2001.

Stephens, C. R., Shepson, P. B., Steffen, A., Bottenheim, J. W., Liao, J., Huey, L. G., Apel, E., Weinheimer, A., Hall, S. R., Cantrell, C., Sive, B. C., Knapp, D. J., Montzka, D. D., and Hornbrook, R S.: The relative importance of chlorine and bromine radicals in the oxidation of atmospheric mercury at Barrow, Alaska, J. Geophys. Res. Atmos., 117, D00R11, doi:10.1029/2011JD016649, 2012.

Talbot, R., Mao, H., Feddersen, D., Smith, M., Kim, S. Y., Sive, B., Haase, K., Ambrose, J., Zhou, Y., and Russo, R.: Comparison of particulate mercury measured with manual and automated methods, Atmosphere, 2, 1-20, 2011.

Tsai, Y. I., Kuo, S. C., and Lin, Y. H.: Temporal characteristics of inhalable mercury and arsenic aerosols in the urban atmosphere in southern Taiwan, Atmos. Environ., 37, 3401-3411, 2003.

Vanarsdale, A., Weiss, J., Keeler, G., Miller, E., Boulet, G., Brulotte, R., and Poissant, L.: Patterns of mercury deposition and concentration in northeastern North America (1996-2002), Ecotoxicology, 14, 37-52, 2005.

Wall, S. M., John, W., and Ondo, J. L.: Measurement of aerosol size distributions for nitrate and major ionic species, Atmos. Environ., 22, 1649-1656, 1988

Wang, Z. W., Zhan, X. S., Chen, Z. S., and Zhang, Y.: Mercury concentrations in size-fractionated airborne particles at urban and suburban sites in Beijing, China, Atmos. Environ., 40, 2194 2201, 2006.

Weiss-Penzias, P., Jaffe, D., Swartzendruber, P., Hafner, W., Chand, D.,and Prestbo, E.: Quantifying Asian and biomass burning sources of mercury using the $\mathrm{Hg} / \mathrm{CO}$ ratio in pollution plumes observed at the Mount Bachelor Observatory, Atmos. Environ., 41, 4366-4379, 2007.

Xiu, G., Cai, J., Zhang, W., Zhang, D., Bueler, A., Lee, S., Shen, Y., Xu, L., Huang, X., and Zhang, P.: Speciated mercury in sizefractionated particles in Shangai ambient air, Atmos. Environ., 43, 3145-3154, 2009.

Zhang, Y., Jaeglé, L., van Donkelaar, A., Martin, R. V., Holmes, C. D., Amos, H. M., Wang, Q., Talbot, R., Artz, R., Brooks, S., Luke, W., Holsen, T. M., Felton, D., Miller, E. K., Perry, K. D., Schmeltz, D., Steffen, A., Tordon, R., Weiss-Penzias, P., and Zsolway, R.: Nested-grid simulation of mercury over North America, Atmos. Chem. Phys., 12, 6095-6111, doi:10.5194/acp12-6095-2012, 2012. 